Research Article

\title{
Chemical Characterization of Specific Micropollutants from Textile Industry Effluents in Fez City, Morocco
}

\author{
Hakima Talouizte, Mohammed Merzouki, Mohammed Benlemlih, \\ and Mohammed Bendriss Amraoui (D) \\ Laboratory of Biotechnology, Environment, Food and Health (LBEFH), Department of Biology, \\ Faculty of Sciences Dhar el Mahrez, P.O. Box 1796 Atlas, Fez, Morocco \\ Correspondence should be addressed to Mohammed Bendriss Amraoui; mohamed.bendrissamraoui@usmba.ac.ma
}

Received 2 May 2020; Accepted 27 May 2020; Published 22 June 2020

Academic Editor: Claudio Cameselle

Copyright ( $) 2020$ Hakima Talouizte et al. This is an open access article distributed under the Creative Commons Attribution License, which permits unrestricted use, distribution, and reproduction in any medium, provided the original work is properly cited.

\begin{abstract}
Textile industry is one of the most polluting industries in the world. It has a high importance in terms of its environment impact, since it consumes a considerably large amount of water and produces highly polluted discharge water. In this work, characterization of toxic organic compounds is proposed. Based on gas chromatography coupled to mass spectrometry (GC/MS) screening analysis, organic micropollutant diversity of textile effluents from a local textile processing factory was investigated. In the present work, physicochemical characterization of the studied textile effluents showed considerably high values of principal pollution parameters above the prescribed discharge water limits. Heavy metals like zinc $(\mathrm{Zn})$, copper $(\mathrm{Cu})$, iron $(\mathrm{Fe})$, nickel $(\mathrm{Ni})$, cadmium $(\mathrm{Cd})$, chromium $(\mathrm{Cr})$, and lead $(\mathrm{Pb})$ were found to be present within the permissible limits. The results of GC/MS revealed the presence of various organic compounds belonging to a wide range of chemical classes. Main groups of chemical compounds detected in these effluents were aromatic carboxylic acids, alkanes, aromatic amines, phthalates, aliphatic carboxylic acids, and linear aliphatic alcohols. The results of this study allowed significant contributions to the chemical characterization of textile industry contaminants and identification of indicators that can be considered an important tool for assessment of the potential impact of textile activities to the contamination of aquatic environment and health hazard.
\end{abstract}

\section{Introduction}

Because of the increase of various types of industrial effluents, there is a growing concern regarding the potentially adverse effects of textile effluents on aquatic biota and humans due to the contamination of water used in textile industry. Being emitted at a significant concentration level, organic compounds in textile effluents normally present a high structural diversity and reveal notable ecotoxicological effects. Determination of nonhalogenated solvents (toluene, xylenes, ethylbenzene, and diisobutylketone) in textile industrial wastewater was performed with head-space solid phase microextraction h-SPME [1]. However, indicative compounds reflecting specific industrial processes and the corresponding chemicals have been reported rarely. More surprisingly, Castillo and Barcelo [2] have reported the appearance of phenol, nonylphenol isomers, and phthalate esters in the effluents of a textile industry in Portugal. Pinheiro et al. [3] and Bilgi and Demir [4] have found that the degradation products of azo dyes, such as 6-acetylamino3-aminonaphthalene-2-sulfonic acid, N-(3,4-bishydroxymethylphenyl) acetamide, aromatic amines, and anilines, can pose a hazard to the aquatic environment. The effects of the contaminants have been investigated in many large-scale studies over a long period of time, and the results are worrisome [5-10].

Significant amounts of polyethylene glycol, polyethoxylate decylalcohol, and linear alkylbenzene sulfonates were found to be major constituents in textile wastewaters. High concentration levels were found for some benzenes and naphthalene sulfonates which are used in the textile industry as dye bath auxiliaries [11]. The authors argued that 
toxicity observed in the effluents from textile industries to Daphnia magna can be attributed to nonylphenol isomers, alcohol polyethoxylated, nonylphenol ethoxylates, and several phthalates. However, most of these studies focused on the contamination of aquatic systems and did not analyze the effect of specific compound composition of the industrial effluents.

Moroccan industrial sector is composed of 6070 units in which $31 \%$ are textile and leather industries. These industries consume significant quantities of dye and chemicals products in the various manufacturing synopsis [12-14]. For wet processing, $1 \mathrm{~kg}$ of cotton needs about $150 \mathrm{l}$ of water, $0.6 \mathrm{~kg}$ $\mathrm{NaCl}$, and $50 \mathrm{~g}$ of reactive dyes [15]. The chemical reagents used in textile industry are diverse in chemical composition ranging from inorganic to organic. Depending on the manufacturing conditions, a significant fraction of the chemicals used is released into the environment through wastewater. Wastewater generated from textile industry, especially dyeing effluents, contain organic dyes, chemicals, auxiliaries, salts, detergents, heavy metals, mineral oils, and high rates of COD [16-18]. Generally, dyeing effluents contain the major part of pollutants generated from textile industry [19] having high $\mathrm{pH}$, temperature, chemical oxygen demand (COD), biological oxygen demand (BOD), total dissolved solids (TDSs), and total suspended solids (TSSs) $[20,21]$ and low biodegradability [22].

The discharge of textile effluents into natural aquatic and terrestrial ecosystems poses serious problems. The hazard linked to these effluents resides mainly in the presence of micropollutants. These chemical compounds are persistent contaminants and bioactive which means that they are not completely biodegradable and cannot be removed with conventional water treatment technologies.

It has to be stated that there is a lack of systematic investigations on organic pollutants in textile effluents as well as of the information on their environmental relevance. Like other city industries in the country, textile industries of Fez city discharge their wastewater into the sewage network without any prior treatment. Moreover, in our previous work, we found high genotoxicity and phytotoxicity potential of textile effluents from the studied site of Fez city [9]. Therefore, due to their complex chemical composition, the present study is focused on (i) physicochemical evaluation of local textile mill effluents in Fez city, Morocco, (ii) characterization of organic pollutants in textile effluents from a local processing factory, and (iii) isolation of specific compounds that might act as source indicators responsible of high toxic load of these effluents. These indicator substances, typical for textile production industries and unique signatures of textile effluents, shall allow efficient source identification in polluted aquatic systems.

\section{Materials and Methods}

2.1. Study Area and Sample Collection. Samples of textile effluent used in this study were collected from a textile factory of $3200 \mathrm{~m}^{2}$ surface, located at Sidi Brahim industrial area in Fez, Morocco. This factory produces cotton and polyester clothes, discharging more than $400 \mathrm{~m}^{3} /$ day of wastewater, which originates from different manufacturing processes (singeing, desizing, scouring, bleaching, mercerizing, dyeing, printing, and finishing). The scheme of sampling site is shown in Figure 1. The wastewater samples were filled in cleaned polyethylene bottles with coated screw caps and stored in the dark at a temperature of $4^{\circ} \mathrm{C}$.

\subsection{Physicochemical Analysis of Textile Effluents.} Physicochemical analyses of textile effluents were performed to evaluate some major parameters including $\mathrm{pH}$, temperature (T), electric conductivity (EC), total suspended solids (TSSs), total dissolved solids (TDSs), chemical oxygen demand (COD), biological oxygen demand during 5 days at $20^{\circ} \mathrm{C}\left(\mathrm{BOD}_{5}\right), \mathrm{P}$-phosphates $\left(\mathrm{P}^{-} \mathrm{PO}_{4}^{3-}\right), \mathrm{N}$-nitrates, and $\mathrm{N}$-nitrites. These parameters were determined in accordance with the method reported by Giorgetti et al. [9].

Metal ions ( $\mathrm{Fe}, \mathrm{Cd}, \mathrm{Pb}, \mathrm{Cr}, \mathrm{Cu}, \mathrm{Zn}$, and $\mathrm{Ni}$ ) and divalent cations $\left(\mathrm{Mg}^{2+}\right.$ and $\left.\mathrm{Ca}^{2+}\right)$ were determined using the plasmaabsorption emission spectroscopy method with an atomic absorption spectrophotometer (Activa, Horiba Jobin Yvon) [9]. The results obtained in experiments were expressed in terms of means (average) and standard deviation (SD). The standard deviation was calculated using Microsoft Excel, and results were presented as mean $\pm \mathrm{SD}$ value.

\subsection{Extraction and Gas Chromatography Coupled to Mass} Spectrometry Analysis. Before subjecting to GC/MS analysis, the organic compounds contained in textile wastewater samples were extracted. A sequential liquid-liquid extraction procedure was applied to approximately $500 \mathrm{ml}$ of textile wastewater using dichloromethane. Equal volume of dichloromethane was used for extraction. Thereafter, the organic layers were concentrated (approx. $1 \mathrm{ml}$ ) by rotary evaporation at $40^{\circ} \mathrm{C}$ under reduced pressure and dried by filtration over $1 \mathrm{~g}$ of anhydrous granulated sodium sulfate. The final concentration volume of wastewater extracts was $50 \mu \mathrm{l}$.

Organic compounds contained in textile wastewater samples were determined in accordance with the method reported by Giorgetti et al. [9] using gas chromatographymass spectrometry under negative chemical ionization mode (Thermo Polaris Q mass spectrometer linked to a TRACE GC Ultra and Thermo Electron Corporation gas chromatograph). The identification of organic compounds was based on comparison of $\mathrm{EIP}^{+}$-mass spectra with those of the reference compounds or mass spectral databases (NIST/ EPA/NIM Mass Spectral Library NIST00, Wiley/NSB Registry of Mass Spectral data) and gas chromatographic retention times. The quantification of organic compounds (relative quantity) was computed from the GC-FID peak areas using the normalization method.

\section{Results and Discussion}

3.1. Physicochemical Characterization of Textile Effluents. The textile effluent samples collected from the studied site during production process were characterized with common parameters (color, temperature, $\mathrm{pH}, \mathrm{EC}, \mathrm{TSS}$, and COD). 


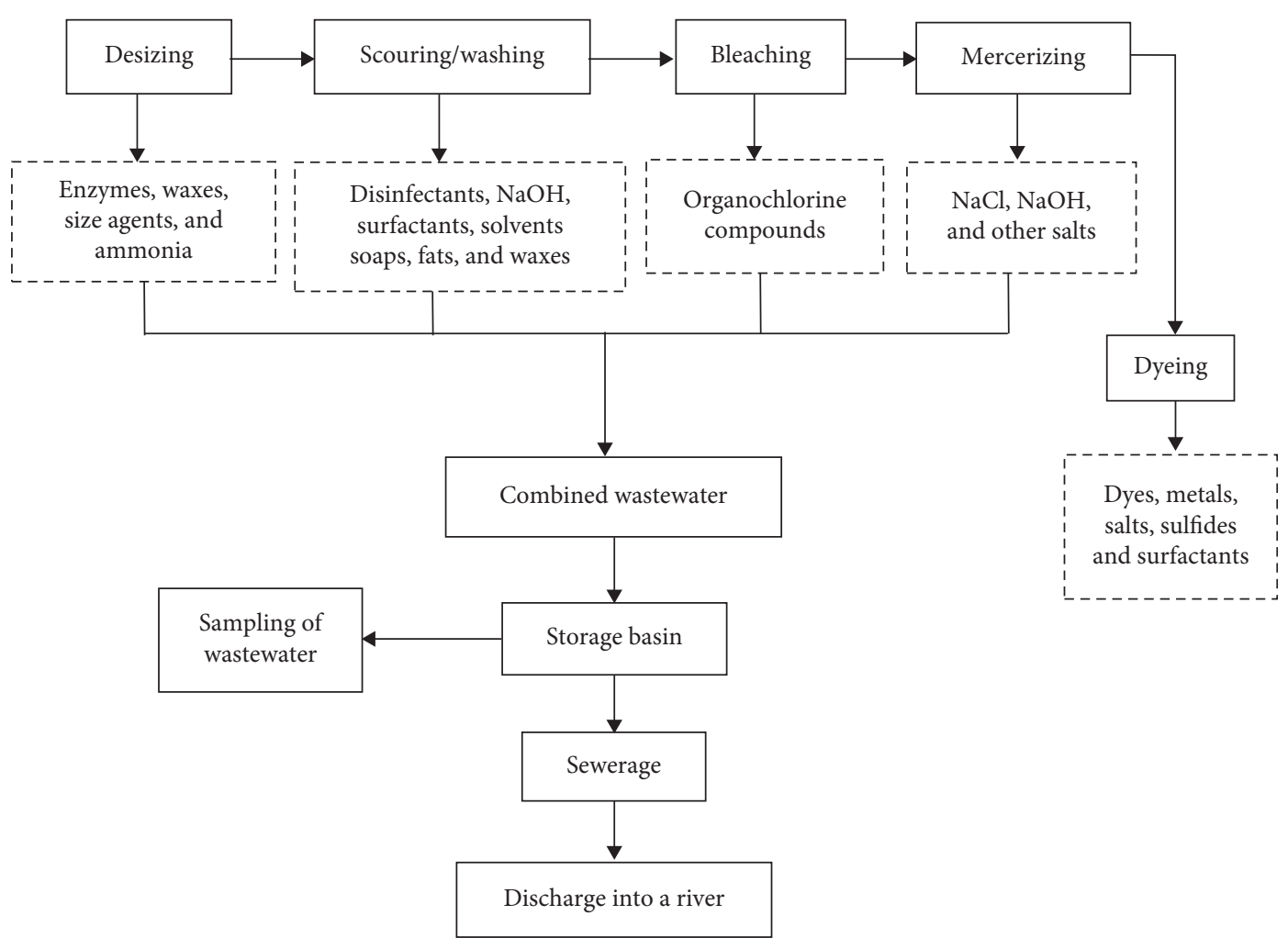

FIGURE 1: Scheme of production processes in sampling site and the main pollutants from each step.

The mean and standard deviations were calculated using 3 different effluents during the experimental period. Main results are presented in Table 1.

The studied textile effluents are characterized by a variation in color from blue, dark blue, and black. This variation of discharged textile effluents color is due to the variation of the dyes and pigments used during production process. The $\mathrm{pH}$ of textile effluent samples varied from 7.2 to 8.1 with a mean value of 7.73 indicating the alkalinity of the effluent samples. The results were similar to the study conducted by Islam and Mostafa [23]. These values of $\mathrm{pH}$ were within the limit set by Moroccan Discharge Quality Standards [24] (M.D.Q.S) and World Health Organization (WHO) standards.

The temperature recorded in textile effluents was high $\left(40-45^{\circ} \mathrm{C}\right)$ and exceeded the standards set by M.D.Q.S and WHO. The high temperature of these effluents can induce corrosion of the sewerage network by catalyzing redox reactions [25]. On the other hand, the elevation of the temperature of these waters facilitates the release of hydrogen sulfide $\left(\mathrm{H}_{2} \mathrm{~S}\right)$ which is a gas with greenhouse effect and dangerous for human health.

The EC indicates dissolved substances in an aqueous system. It depends on the dissociation of ions, their concentration, temperature, and migration in the electric field, but it does not give any idea about the type of ions present [26]. The EC average of textile effluents was $5476.66 \mu \mathrm{s} \mathrm{cm}^{-1}$, which is higher than the permissible limits set by M.D.Q.S and WHO indicating the high levels of pollution. The results are similar to those published by Ali et al. [27]. The total dissolved solids (TDSs) are the organic contaminants and inorganic insoluble, suspended particles, sulfates, phosphates, sodium chloride, etc., which ruffled the water quality [28].

The amount of TDS which was found to be 1510, 3025, and $2400 \mathrm{mg} \cdot \mathrm{l}^{-1}$, respectively, in the textile effluents A, B, and $\mathrm{C}$ was similar to the observation made by Ali et al. [27]. These effluents show TDS concentrations higher than the permissible limits set by M.D.Q.S and WHO (TDS average $=2311.11 \mathrm{mg} \cdot \mathrm{l}^{-1}$ ) indicating that the discharged effluents have the potential to deteriorate the surface water quality and aquatic life as well. The total suspended solids (TSSs) of textile effluent samples were found to be in the range of $900-2200 \mathrm{mg} \cdot \mathrm{l}^{-1}$, which is slightly similar to the results shown by Ali et al. [27] and varied from 400 to $1500 \mathrm{mg} \mathrm{l}^{-1}$. All these TSS values are notably higher than the permissible limit of TSS as per M.D.Q.S and WHO standard (30 and $100 \mathrm{mg} \cdot \mathrm{l}^{-1}$, respectively).

Chemical oxygen demand (COD) shows the presence of both the biodegradable and non-biodegradable matter content in the textile effluents. In this study, total COD in various textile effluents varied from 1026 to $2433 \mathrm{mg} \cdot \mathrm{l}^{-1}$, exceeding the limits set by M.D.Q.S and WHO. Shammi et al. [29] reported that the COD of textile effluents was found between 832 and $1023 \mathrm{mg} \cdot \mathrm{l}^{-1}$, which were lower than the present findings. The highest COD value was recorded in effluent $B$ and the lowest was found in effluent A. Biological oxygen demand $\left(\mathrm{BOD}_{5}\right)$ measures the amount of oxygen used by microorganisms in the biological process in water. $\mathrm{BOD}_{5}$ is found to be higher in all the samples indicating the 
TABLe 1: Physicochemical characterization of textile effluents compared with M.D.Q.S and WHO standards.

\begin{tabular}{|c|c|c|c|c|c|c|c|c|}
\hline Parameters & Units & M.D.Q.S limits & WHO standards & Effluent A & Effluent B & Effluent C & Average & S.D $( \pm)$ \\
\hline Color & - & - & - & Blue & Dark blue & Black & - & - \\
\hline $\mathrm{T}$ & ${ }^{\circ} \mathrm{C}$ & 30 & 40 & 45 & 40 & 41 & 42 & 2.64 \\
\hline $\mathrm{pH}$ & & $5.5-8.5$ & $6.5-8.5$ & 7.2 & 7.9 & 8.1 & 7.73 & 0.47 \\
\hline EC & $\mu \mathrm{s} \cdot \mathrm{cm}^{-1}$ & 2700 & 1200 & 1240 & 13670 & 1520 & 5476.66 & 7097.01 \\
\hline TDS & $\mathrm{mg} \cdot \mathrm{l}^{-1}$ & - & 2000 & 1510 & 3025 & 2400 & 2311.66 & 761.35 \\
\hline TSS & $\mathrm{mg} \cdot \mathrm{l}^{-1}$ & 30 & 100 & 900 & 2200 & 1200 & 1433.33 & 680.68 \\
\hline COD & $\mathrm{mg} \cdot \mathrm{l}^{-1}$ & 120 & 250 & 1026 & 2433 & 1766 & 1741.66 & 706.81 \\
\hline BOD & $\mathrm{mg} \cdot \mathrm{l}^{-1}$ & 40 & 30 & 200 & 880 & 360 & 480 & 355.52 \\
\hline $\mathrm{P}-\mathrm{PO}_{4}^{3-}$ & $\mathrm{mg} \cdot \mathrm{l}^{-1}$ & - & - & 0.461 & 0.788 & 1.147 & 0.798 & 0.343 \\
\hline $\mathrm{N}-\mathrm{NH}_{4}^{+}$ & $\mathrm{mg} \cdot \mathrm{l}^{-1}$ & - & - & 0.670 & 1 & 7.3 & 2.99 & 3.73 \\
\hline $\mathrm{N}-\mathrm{NO}_{3}^{-}$ & $\mathrm{mg} \cdot \mathrm{l}^{-1}$ & - & - & 10.8 & 0.29 & 1.45 & 4.18 & 5.76 \\
\hline $\mathrm{Ca}$ & $\mathrm{mg} \cdot \mathrm{l}^{-1}$ & - & - & 88.54 & 210.44 & 13.8 & 104.26 & 99.25 \\
\hline $\mathrm{Mg}$ & $\mathrm{mg} \cdot \mathrm{l}^{-1}$ & - & - & 25.29 & 51.97 & 4.85 & 27.37 & 23.62 \\
\hline $\mathrm{Zn}$ & $\mathrm{mg} \cdot \mathrm{l}^{-1}$ & 5 & 1 & 0.04 & 0.28 & 0.05 & 0.123 & 0.13 \\
\hline $\mathrm{Cu}$ & $\mathrm{mg} \cdot \mathrm{l}^{-1}$ & 3 & 0.1 & 0.004 & 0.032 & 0.002 & 0.0126 & 0.016 \\
\hline $\mathrm{Fe}$ & $\mathrm{mg} \cdot \mathrm{l}^{-1}$ & 5 & 10 & 0.649 & 0.584 & 0.401 & 0.544 & 0.128 \\
\hline $\mathrm{Ni}$ & $\mathrm{mg} \cdot \mathrm{l}^{-1}$ & 5 & 3 & 0.02 & 0.01 & 0.001 & 0.010 & 0.009 \\
\hline $\mathrm{Pb}$ & $\mathrm{mg} \cdot \mathrm{l}^{-1}$ & 1 & 0.1 & 0.05 & 0.002 & 0.03 & 0.031 & 0.024 \\
\hline $\mathrm{Cd}$ & $\mathrm{mg} \cdot \mathrm{l}^{-1}$ & 0.2 & 2 & 0.001 & 0.032 & 0.041 & 0.024 & 0.020 \\
\hline $\mathrm{Cr}$ & $\mathrm{mg} \cdot \mathrm{l}^{-1}$ & 0.5 & 2 & 0.021 & 0.011 & 0.045 & 0.025 & 0.017 \\
\hline
\end{tabular}

more percentage of bacterial content utilizing the oxygen, probably due to the presence of higher organic content in the samples [28].

The amount of $\mathrm{N}$-Nitrate $\left(\mathrm{N}-\mathrm{NO}_{3}^{-}\right)$in studied effluents averaged $4.18 \mathrm{mg} \cdot \mathrm{l}^{-1}$, which was higher than the results of Somensi et al. [30]. N-Nitrite $\left(\mathrm{N}-\mathrm{NH}_{4}^{+}\right)$averaged $2.99 \mathrm{mg} \cdot \mathrm{l}^{-1}$ which was lower than the findings of Fang et al. [31]. Concerning $\mathrm{P}$-Phosphate $\left(\mathrm{P}-\mathrm{PO}_{4}^{3-}\right)$, low concentrations were recorded in textile effluent samples (average $=0.798 \mathrm{mg} \cdot \mathrm{l}^{-1}$ ), which were lower than the results of Somensi et al. [30].

Divalent cations $\mathrm{Ca}^{2+}$ and $\mathrm{Mg}^{2+}$ showed high concentration $\left(\mathrm{mg} \cdot \mathrm{l}^{-1}\right)$ variability in the effluent samples, reflected by high standard deviation values (104.26 \pm 99.25 and $27.37 \pm 23.62$, respectively). Finally, heavy metal analysis of textile effluents showed low concentrations compared to the M.D.Q.S and WHO standard. The average concentration $\left(\mathrm{mg} \mathrm{l}^{-1}\right)$ of heavy metals like $\mathrm{Cu}(0.0126)$, $\mathrm{Ni}(0.01), \mathrm{Pb}$ (0.031), Cd (0.024), and Cr (III) (0.025) was considerably low $\left(<0.04 \mathrm{mg} \cdot \mathrm{l}^{-1}\right)$ while it kept $>0.1 \mathrm{mg} \mathrm{l}^{-1}$ in case of $\mathrm{Zn}(0.13)$ and $\mathrm{Fe}(0.544)$. The relative dominance (average) of heavy metals in textile effluents was observed in the following sequence: $\mathrm{Fe}>\mathrm{Zn}>\mathrm{Pb}>\mathrm{Cr}>\mathrm{Cd}>\mathrm{Cu}>\mathrm{Ni}$.

Table 1 shows great variability in the quality of textile effluents and revealed a reasonably high load of pollution indicators compared to the prescribed M.D.Q.S and WHO limits. Color of textile effluents is due to dyes and pigments dissolved in water that absorb light and emit light at specific wavelengths. Coloration of textile effluents is a great environmental concern since it reduces the oxygen concentration in water due to the presence of hydrosulfide group compounds. Also, it blocks the passage of light through the water body and is detrimental to the water ecosystem [32].The temperature of textile effluent was considerably high (average $=42^{\circ} \mathrm{C}$ ) which reduces solubility of gases in water that is ultimately expressed as low $\mathrm{BOD}_{5} / \mathrm{COD}$. The $\mathrm{BOD}_{5} / \mathrm{COD}$ ratio was 0.27 (average), which was very low in comparison to domestic wastewater (0.5). Therefore, the biodegradability of the effluent was found to be low according to the criteria of Ahn et al. [33].Generally, alkaline $\mathrm{pH}$ of textile effluents is associated with the process of bleaching [34-38], and it is extremely undesirable in water ecosystems. Conductivity is a pollution parameter which is sensitive to variation in dissolved ions and mineral salts [39]. Electric conductivity recorded in textile effluent was considerably high and reflected a high concentration of mineral salt.

There was observed high values of TSS and TDS in effluent samples which correspond to filterable and nonfilterable residues, respectively. TSS and TDS are important repositories for toxic heavy metals and dyes [40, 41] causing rapid depletion of dissolved oxygen leading to oxygen sag in the receiving water [42]. Even if the levels of metal ion concentrations in effluents were low and reached the permissible limits of M.D.Q.S and WHO, they are considered toxic and tend to persist indefinitely, circulating and eventually accumulating throughout the food chain [27, 43-45]. The inorganic heavy metals, such as $\mathrm{Cd}, \mathrm{Cu}, \mathrm{Cr}$, $\mathrm{Fe}, \mathrm{Mn}, \mathrm{Ni}$, and $\mathrm{Zn}$, originating from ionic salts are directly absorbed by the marine and fresh water biota or are incorporated in ground water in both cases, i.e., the consumption of polluted ground water and marine foods may lead to diseases like cancer, brain diseases, and psychiatric diseases. Concerning heavy metals present in textile dyes as a chromophoric group, they are not biodegradable; hence, they accumulate in primary organs in the body and lead to various symptoms of diseases [46].

Similar to the toxic dyes and pigments of organic nature, such as C.I. Pigment Yellow-12 (3,3-dichloro benzedine), C.I. Disperse Yellow-7 (P-amino azobenzene), and C.I. Direct Yellow-1 (benzedine), salts, acids, alkalis, and bleaching and finishing agents are also highly harmful and affect the health of biota to a great extent. The effects of the 
pollutants may not be quite evident immediately but with the passage of time their imperceptible effects are of fatal nature [47]. Hence, the presence of dyes and metals cause severe damage to the aquatic biology. Consequently, the selfpurification ability of the stream and conventional biological treatment systems are hindered [42].

It can then be concluded that the textile wastewater used in this experiment was highly variable and suffered from low biodegradability and high inorganic solid content (both soluble and suspended). This wide variation in the characteristics of textile wastewater is due to the complexity of materials used in the textile industry during the processing of textiles.

3.2. Organic Compounds of Textile Effluents. Textile effluents from the studied site were subject to organic analyses. Based on the GC/MS analysis of different textile effluents from the studied site, identification of a large number of various organic contaminants has been performed. The obtained results demonstrated high structural diversity of organic chemical pollutants in the textile wastewaters. It is important to notice that only a restricted number of samples have been investigated as a preliminary evaluation of a potential impact of textile contaminants from diverse production processes at industrial site on the aquatic environment. Selected environmentally relevant specific organic compounds identified in three different textile effluents are presented in Tables 2-4 and are arranged according to their retention time. The chromatograms of extracts containing various organic constituents in terms of structural diversity and quantitative composition of textile effluents $\mathrm{A}, \mathrm{B}$, and $\mathrm{C}$ are illustrated in Figures 2-4 (peak numbers correspond to the organic compounds shown in Tables 2-4).

Fast characterization of the identified compounds revealed the presence of organic pollutants belonging to a wide range of chemical classes such as aromatic carboxylic acids, alkanes, benzoic compounds, phthalates, aliphatic carboxylic acids, aromatic amines, and linear aliphatic alcohols (Tables 2-4). Generally, aromatic carboxylic acids were predominant in effluent A. 1,2-Benzendicarboxylic acid, 4-methyl-dimethyl ester; benzoic acid, 2,3-dimethyl-6-(3-methyl-1-oxobutyl); propane dioic acid (3chlorophenyl) methylene, diethyl ester; and benzoic acid, 4-(tetrazol-1-yl) methyl were detected with a relative abundance (RA) of $37.3,14.5,1.08$, and $0.16 \%$, respectively (peaks 5, 4, 12, and 10, respectively, in Figure 2).

Aromatic carboxylic acids present in textile effluents are reported to be constituents of natural tanning agents and dyes [11]. Referring to the group of alkanes, 2-pentoxy-tetrahydropyran, 2-propyltetrahydropyran, and 2,2-dimethylbutane were the predominant ones with RA of 17.45 (peak 2), 3.72 (peak 3) and 1.58\% (peak 1), respectively (Figure 2). 2-Ethylthiolane, S,S-dioxide was identified as a sulfur containing compound with RA of $12.83 \%$ (peak 7 in Figure 2). Aliphatic carboxylic acids were detected from $\mathrm{C} 2$ to $\mathrm{C} 6$ (e.g., methane carboxylic acid and acetic acid, 1-methyl ester (peak 9 and 6 in Figure 2)). It has been reported that the short chain of carboxylic acids detected in textile effluents has a metabolic origin and the long chain of carboxylic acids is originating from fatty acids, fatting agents, and microbial biomass [11]. Concerning the group of phenols, phenol,4-[2-[2-(chloromethyl)-1,3- dioxolan-2-yl]ethyl]-, acetate was detected ( $\mathrm{RA}=0.10 \%$, Table 2). It is reported that phenols detected in samples from textile industry are used in the manufacture of dyes [3]. Phenolic compounds are toxic and their toxicity can be explained by the substitution of this surface-active agent with new products, as polyethoxylated alcohols. It was reported a correlation with toxicity accumulation and oestrogenic effects that phenolic compounds are induced in some animals and organisms [48]. Regular monitoring of phenolic compounds is essential due to their toxicity and bioaccumulation effects in animals and plants [48].

Other compounds were also present in the studied wastewater such as linear aliphatic alcohols (e.g., ethyl alcohol and acetol; Table 2) and chlorinated compounds (e.g., Benzene, 1-chloro-2-diethoxymethyl- (peak 11, Figure 2) and propanedioic acid, (3chlorophenyl) methylene, and diethyl ester (peak 12, Figure 2)). Linear aliphatic alcohols are used in textile industry as solvents and antifoaming agents; chlorinated compounds are known as a by-product of bleaching step during textile processing [49]. Some epidemiological studies have shown the association between exposure to chlorination by-products and the increased risk of low birth weight, congenital abnormalities (neural tube defects and heart abnormalities) [50-52], spontaneous abortion [53-55], and death at birth [56, 57].

Concerning textile effluent $\mathrm{B}$, we note the predominance of two toxic compounds: phtalimide dioxime acetamide $(\mathrm{RA}=30.45 \%$, peak 13 in Figure 3$)$ and N-benzyl-2-(2,3dihydro-2-methyl-5-phenyl-1,3,4-thiadiazol-2-yl)

$(\mathrm{RA}=47.35 \%$, peak 14 in Figure 3) belonging to chemical group of phthalates and nitrobenzyl, respectively. The chromatogram obtained for textile effluent $B$ (the more toxic one) and the spectrum corresponding to both predominant toxic compounds are shown in Figure 3.

This complex effluent also contains aromatic carboxylic acids (acid, 2,4-bis[(trimethylsilyl)oxy]-, trimethylsilyl ester (peak 17, Figure 3)), aliphatic carboxylic acids (methane carbothiolic acid (peak 9, Figure 3)), and alkanes (ethane, 1,1diethoxy (peak 15, Figure 3)). Like effluent A, this effluent also contains aliphatic alcohols (ethanol, 2-(1-methylethoxy)(RA $=0.47 \%$; Table 3$)$ and aliphatic carboxylic acids (pentanoic acid, 3-methyl-4-oxo, (RA $=0.17 \%$; Table 3$)$, butanoic acid, 2-methyl-, ethyl ester $(\mathrm{RA}=0.13 \%$; Table 3$)$ and butanedioic acid, diethyl ester, (RA $=0.25 \%$; Table 3$)$ ) but at less abundance. Benzoic compounds such as benzene, 1-methyl2-propyl; benzene, (1,2-dimethoxyethyl)-; and benzene, 1chloro-2-diethoxymethyl- (peaks 16,18, and 20, respectively, Figure 3) were detected with RA $<0.9 \%$.

As described in Table 4, textile effluent $\mathrm{C}$ is characterized by the presence of important amounts of toxic aromatic amines and phtalates (naphtho[2,3-d]-1,3-dioxol-5-ol, 3a,4,9,9a-tetrahydro-2,2-dimethyl-, cis; RA =14.10\%; peak 29, Figure 4). The derivatives of phthalate (DBP, DEP, and BEP) are commonly used as wetting agent, dispersant, and softener in the application of disperse dyes and also as a plasticizer for polyvinylchloride (PVC). For example, the 3-nitrophthalic acid is used in the preparation of quinophthalene series of dyes which are useful in dyeing of hydrophobic fibers like nylon and polyester [58] as is the case in the factory of Fez city. 
TABLE 2: Organic compounds identified in real textile effluent A.

\begin{tabular}{|c|c|c|}
\hline Compound & $\mathrm{RT}(\min )$ & RA (\%) \\
\hline Ethyl alcohol & 4.35 & 0.11 \\
\hline Tert-butyl hydroperoxide & 4.89 & 0.32 \\
\hline Methane, trimethoxy- & 5.38 & 0.20 \\
\hline Butane, 2,2-dimethyl- ${ }^{1}$ & 6.11 & 1.58 \\
\hline 2-Pentoxy-tetrahydropyran ${ }^{2}$ & 6.95 & 17.45 \\
\hline 2-Propyltetrahydropyran ${ }^{3}$ & 7.30 & 3.72 \\
\hline Benzoic acid, 2,3-dimethyl-6-(3-methyl-1-oxobutyl) ${ }^{4}$ & 7.70 & 14.5 \\
\hline 1,2-Benzendicarboxylic acid, 4-methyl-, dimethyl ester ${ }^{5}$ & 8.09 & 37.3 \\
\hline Acetic acid, 1-methyl ester ${ }^{6}$ & 8.41 & 1.66 \\
\hline 2-Ethylthiolane, S,S-dioxide ${ }^{7}$ & 8.76 & 12.89 \\
\hline Pentane, 2,2-dimethyl- & 9.08 & 0.17 \\
\hline Acetic acid, 1-methylethyl ester & 9.41 & 0.13 \\
\hline Cyclohexane & 9.93 & 0.34 \\
\hline Hexane, 2,4-dimethyl- & 10.09 & 0.13 \\
\hline Hydroxylamine,O-(2 methylpropyl) & 10.20 & 0.10 \\
\hline Diacetyl sulfide & 10.90 & 0.29 \\
\hline Propanoic acid, ethyl ester & 11.04 & 0.13 \\
\hline Toluene $^{8}$ & 13.49 & 0.24 \\
\hline Acetaldehyde, tetramer & 14.70 & 0.30 \\
\hline 2-(Acetomethyl)-1- butene & 15.00 & 0.21 \\
\hline Isocrotonic acid (2-Butanoic acid) & 15.28 & 0.32 \\
\hline Acetol & 15.69 & 0.23 \\
\hline Methanecarbothilic acid ${ }^{9}$ & 17.96 & 1.53 \\
\hline Acetic acid, ethoxy-, ethyl ester & 18.14 & 0.11 \\
\hline Ketone, methyl 2-methyl-1,3-oxothiolan-2-yl & 19.14 & 0.31 \\
\hline Oxirane, (1-methylbutyl)- & 20.44 & 0.35 \\
\hline 2-Isopropyl-3-vinyloxirane & 20.97 & 0.10 \\
\hline Glyceraldehyde diethylacetal & 24.39 & 0.22 \\
\hline Benzene, 1-methyl-2-(1-methylethyl)- & 25.10 & 0.18 \\
\hline Undecane, 2,6-dimethyl- & 25.93 & 0.19 \\
\hline Octadecane, 3-ethyl-5-(2-ethylbutyl)- & 26.57 & 0.09 \\
\hline Pentadecanoic acid,2,6,10,14-tetramethyl-, methyl ester & 26.74 & 0.10 \\
\hline 1-Butanol, 3-methyl-, acetate & 29.80 & 0.21 \\
\hline Benzoic acid, 4-(tetrazol-1-yl) methyl- ${ }^{10}$ & 43.13 & 0.16 \\
\hline 4-Nitrobenzyl idenene malonic acid, diethyl ester & 43.53 & 0.45 \\
\hline Benzene, 1-chloro-2-diethoxymethyl- ${ }^{11}$ & 46.69 & 0.47 \\
\hline Propanedioic acid, (3chlorophenyl) methylene, diethyl ester ${ }^{12}$ & 47.09 & 1.08 \\
\hline Ethanol,2-[4-(1,1dimethylethyl)phenoxy] & 48.01 & 0.12 \\
\hline Phenol,4-[2-[2-(chloromethyl)-1,3-dioxolan-2-yl]ethyl]-, acetate & 48.33 & 0.10 \\
\hline Propane dioic acid, [(4methoxyphenyl) methylene]-, diethyl ester & 49.37 & 0.25 \\
\hline Cyclohexane-1,3-dicarboxylic acid, 2-(4-methoxyphenyl)-4,6-dioxo-, diethyl ester & 53.26 & 0.12 \\
\hline Hexadecane, 2-methyl- & 53.36 & 0.12 \\
\hline Tetratriacontane & 54.35 & 0.09 \\
\hline 2-Secoandrosta-1,6-diene-17,19-diol,2-cyano-4-methylene-, diacetate & 55.76 & 0.59 \\
\hline 10a,12a-Dimethyl-hexadecahydro-2-oxa-chrysen-3-one & 56.91 & 0.13 \\
\hline Phthalic acid, 6-ethyloct-3-yl 2-ethylhexyl ester & 59.03 & 0.39 \\
\hline Dodecanoic acid & 60.79 & 0.10 \\
\hline Docosanoic acid, 2-hydroxy-, methyl ester & 61.95 & 0.12 \\
\hline
\end{tabular}

RT: retention time; RA: relative abundance. ${ }^{1-12}$ Organic compounds corresponding to peak numbers on the chromatogram referring to effluent A in Figure 2.

Aromatic amines 2-amino-4-hydroxy-6-p-cyanophenylpropylpteridine and 3-amino-3-(2,4-dichloro-phenyl)propionic acid are the dominant ones with RA of 32.81 and $11.59 \%$, respectively (peaks 26 and 27, Figure 4). 2,6-Diamino-4-cyclohexyl-4H-thiopyran-3,5-dicarbonitrile is a nitro substituted aromatic compound detected in this effluent at considerable RA of $15.78 \%$ (peak 28, Figure 4).

Azo dyes are recalcitrant, non-biodegradable, and persistent among all chemical classes of dyes. Aromatic amines detected in the studied effluents are the result of the reduction of the azo bond of azo dyes. The first concerns with human exposure to carcinogenic aromatic amines arose in the dye manufacturing industry as early as the late nineteenth century [5]. Therefore, most of the attention concerning the possible hazards arising from the use of azo dyes has been transferred to their reduction products [59-61]. The formation of a carcinogenic amine from the dye Direct Blue 14 by human skin bacteria [62] and the antifungal activity of 13 diazobenzene dyes have been established $[63,64]$. 
TABLE 3: Organic compounds identified in real textile effluent B.

\begin{tabular}{|c|c|c|}
\hline Compound & RT (min) & RA (\%) \\
\hline Acetone & 4.83 & 0.32 \\
\hline Formic acid, ethyl ester & 5.40 & 0.25 \\
\hline Methylglyoxal & 7.24 & 0.28 \\
\hline Phthalimide dioxime $e^{13}$ & 7.74 & 30.45 \\
\hline Acetamide, N-benzyl-2-(2,3-dihydro-2-methyl-5-phenyl-1,3,4-thiadiazol-2-yl) ${ }^{14}$ & 8.24 & 47.35 \\
\hline Methane carbothiolic acid ${ }^{9}$ & 8.63 & 3.36 \\
\hline Acetic acid, 1-methylethyl ester & 9.47 & 0.48 \\
\hline Ethaneperoxoic acid, 1-cyano-1-(2-methylphenyl)ethyl ester & 10.94 & 0.37 \\
\hline Propanoic acid, ethyl ester & 11.07 & 0.42 \\
\hline Ethane, 1,1-diethoxy- ${ }^{15}$ & 12.00 & 1.31 \\
\hline Cyclobutene, 2-propenylidene- & 13.51 & 0.57 \\
\hline Ethanol, 2-(1-methylethoxy)- & 14.70 & 0.47 \\
\hline Acetic acid, 1-methylethyl ester & 15.02 & 0.28 \\
\hline Isocrotonic acid & 15.37 & 0.66 \\
\hline Diacetyl sulfide & 15.69 & 0.34 \\
\hline Methanecarbothiolic acid ${ }^{9}$ & 17.97 & 2.56 \\
\hline Acetic acid, ethoxy-, ethyl ester & 18.15 & 0.18 \\
\hline Pentanoic acid, 3-methyl-4-oxo- & 18.50 & 0.17 \\
\hline Ketone, methyl 2-methyl-1,3-oxothiolan-2-yl & 19.15 & 0.48 \\
\hline Butanoic acid, 2-methyl-, ethyl ester & 20.43 & 0.13 \\
\hline Undecane, 2,6-dimethyl- & 22.52 & 0.18 \\
\hline 2,3-Butane diol-diacetate & 23.43 & 0.15 \\
\hline 1,1-Ethanediol, diacetate & 24.19 & 0.15 \\
\hline Glyceraldehyde diethylacetal & 24.39 & 0.38 \\
\hline Benzene, 1-methyl-2-propyl- ${ }^{16}$ & 24.76 & 0.16 \\
\hline 2,3-Dimethyldecane & 25.00 & 0.13 \\
\hline Ethyl -3-acetoxybutyrate & 25.17 & 0.42 \\
\hline Octane, 5-ethyl-2-methyl- & 25.93 & 0.40 \\
\hline Methanol, oxo-, benzoate & 26.94 & 0.15 \\
\hline Butanedioic acid, diethyl ester & 27.33 & 0.25 \\
\hline 4,4-Ethylenedioxy-1-pentylamine & 27.75 & 0.15 \\
\hline Methoxyacetaldehyde diethyl acetal & 27.89 & 0.21 \\
\hline 1-Butanol, 3-methyl-, acetate & 29.81 & 0.34 \\
\hline Benzoic acid, 2,4-bis[(trimethylsilyl)oxy]-, trimethylsilyl ester ${ }^{17}$ & 41.81 & 0.27 \\
\hline Benzene, (1-ethoxy-3-butenyl)- ${ }^{18}$ & 43.12 & 0.29 \\
\hline Propanedioic acid, (phenylmethylene)-, diethyl ester ${ }^{19}$ & 43.53 & 0.72 \\
\hline Benzene, 1-chloro-2-diethoxymethyl- ${ }^{20}$ & 46.70 & 0.85 \\
\hline Propanedioic acid, [(3-chlorophenyl)methylene]-, diethyl ester ${ }^{21}$ & 47.09 & 1.58 \\
\hline (5-Chloro-3-cyano-4,6-dimethyl-pyridin-2-ylsulfanyl)-acetic acid ethyl ester & 47.74 & 0.14 \\
\hline Propanedioic acid, [(4-methoxyphenyl)methylene]-, diethyl ester & 49.37 & 0.37 \\
\hline Benzofurane-3-carboxylic acid, 5-methoxy-2-(1-piperidylmethyl)-, ethyl ester & 53.25 & 0.14 \\
\hline 2-Isopropyl-10-methylphenanthrene & 53.56 & 0.15 \\
\hline 1-Methyl-2,6-diphenyl-4,4-tetramethylene-1,4-dihydropyridine-3,5-dicarbonitrile & 55.76 & 0.83 \\
\hline
\end{tabular}

RT: retention time; RA: relative abundance. ${ }^{13-21}$ Organic compounds corresponding to peak numbers on the chromatogram referring to effluent B in Figure 3.

Since the 1890s, the increase in bladder cancer has been observed among employees working in the dyeing department of textile industry, which is related to their exposition to aromatic amines [65]. These compounds are biorefractory and highly toxic since they can react easily in the blood to convert hemoglobin into methemoglobin, thus preventing the absorption of oxygen [66]. In human beings, these toxic compounds are often metabolized in their acyloxyamine derivatives which bind to guanine, thus altering the DNA [67].

As described in this paper, benzoic derivatives are indicative compounds of textile effluents. Effluent $\mathrm{C}$ contains considerable amounts of these compounds; benzene, 1-(2,2dimethoxyethyl)-4-methoxy ( $\mathrm{RA}=12.48 \%)$ and benzene, $(1,2$-dimethoxyethyl)-( $\mathrm{RA}=6.03 \%)$ are major benzoic compounds in this effluent (peaks 24 and 25, Figure 4). Aromatic carboxylic acids present in the studied effluents are a constituent of natural tanning agents and dyes [11]. Linear aliphatic alcohols are used as solvent and antifoaming agents; concerning chlorinated compounds, they are a byproduct of bleaching step during textile processing [49]. Phenols detected in samples from the textile industry are used in the manufacture of dyes [3]. Phenol free radicals are responsible for cardiovascular diseases and occupational and environmental lung diseases [68]. Phenols substituted with electron-releasing molecules can frame conceivably poisonous phenoxyl free radicals. Those substituted phenols with electron pulling back impact have high lethality for organisms, which is linked to their lipophilicity [69]. 
TABLe 4: Organic compounds identified in real textile effluent C.

\begin{tabular}{|c|c|c|}
\hline Compound & $\mathrm{RT}(\min )$ & RA (\%) \\
\hline Hydroxylamine, $O$-methyl- & 4.08 & 0.94 \\
\hline Ethane, 2-chloro-1,1-dimethoxy- ${ }^{22}$ & 4.28 & 1.85 \\
\hline Tricyclo[6.3.0.0(2,6)] undecan-10-one, 3 -[(2-methoxyethoxy)methoxy]-2-methyl- ${ }^{23}$ & 4.73 & 3.78 \\
\hline Benzene, (1,2,2-trimethoxyethyl)- & 5.13 & 0.03 \\
\hline 8a-Methyl-5-methylene-3-([(pyridin-2-ylmethyl)-amino]-methyl)-decahydro-naphtho[2,3-b]furan-2-one & 5.18 & 0.03 \\
\hline Benzene, 1-(2,2-dimethoxyethyl)-4-methoxy- ${ }^{24}$ & 5.86 & 12.48 \\
\hline \multicolumn{3}{|l|}{ Tyramine, N-aminoacetyl- } \\
\hline Benzene, (1,2-dimethoxyethyl)- ${ }^{25}$ & 6.30 & 6.03 \\
\hline Butanoic acid, 3-hydroxy-3-methyl- & 6.74 & 0.04 \\
\hline Acetic acid, hydrazide & 6.95 & 0.01 \\
\hline Propanoic acid, 2,2-dimethyl-, hydrazide & 7.11 & 0.01 \\
\hline 2-Amino-4-hydroxy-6-p-cyanophenylpropylpteridine $\mathrm{e}^{26}$ & 7.49 & 5.65 \\
\hline 2-Amino-4-hydroxy-6-p-cyanophenylpropylpteridine $\mathrm{e}^{26}$ & 7.69 & 27.16 \\
\hline 3-Amino-3-(2,4-dichloro-phenyl)-propionic acid ${ }^{27}$ & 7.85 & 11.59 \\
\hline 2,6-Diamino-4-cyclohexyl-4H-thiopyran-3,5-dicarbonitrile ${ }^{28}$ & 8.33 & 15.78 \\
\hline Naphtho[2,3-d]-1,3-dioxol-5-ol, 3a,4,9,9a-tetrahydro-2,2-dimethyl-, cis- $^{29}$ & 9.56 & 14.10 \\
\hline Disulfide, propyl 1-(propylthio)ethyl & 9.61 & 0.06 \\
\hline Oxalic acid, ethyl propyl ester & 11.13 & 0.02 \\
\hline Toluene $^{8}$ & 13.40 & 0.12 \\
\hline 4-Penten-2-one & 14.83 & 0.01 \\
\hline Nitroxide, bis(1,1-dimethylethyl) & 15.38 & 0.01 \\
\hline Pent-2-ynal, 4,4-dimethyl- & 25.30 & 0.01 \\
\hline 1,3,7-Octatriene, 3,7-dimethyl- & 25.41 & 0.01 \\
\hline 2-Butanol, (ñ)- & 27.32 & 0.03 \\
\hline 2,5-Diethylphenol & 31.06 & 0.03 \\
\hline Benzenemethanol, 4-(1-methylethyl)- & 31.42 & 0.01 \\
\hline 1,5-Decadiyne & 32.54 & 0.01 \\
\hline 1,2-Benzenedicarboxylic acid, mono(2-ethylhexyl) ester & 44.10 & 0.08 \\
\hline Octadecane, 6-methyl- & 45.59 & 0.01 \\
\hline n-Hexadecanoic acid & 47.39 & 0.01 \\
\hline 3,7,11,15-Tetramethylhexadeca-1,3,6,10,14-pentaene & 47.70 & 0.01 \\
\hline 7,11,15-Trimethyl-3-methylene-hexadeca-1,6,10,14-tetraene & 47.86 & 0.01 \\
\hline $\begin{array}{l}\text { 1H-2,8a-Methanocyclopenta[a]cyclopropa[e]cyclodecen-11-one, 1a,2,5,5a,6,9,10,10a-octahydro-5,5a,6-trihydroxy- } \\
\text { 1,4-bis(hydroxymethyl)-1,7,9-trimethyl-, [1S-(1à,1aà,2à,5á,5aá,6á,8aà,9à,10aà)]- }\end{array}$ & 50.89 & 0.01 \\
\hline 5-Benzofuranacetic acid, 6-ethenyl-2,4,5,6,7,7a-hexahydro-3,6-dimethyl-à-methylene-2-oxo-, methyl ester & 51.73 & 0.01 \\
\hline Heptadecane, 2,3-dimethyl- & 55.67 & 0.04 \\
\hline
\end{tabular}

RT: retention time; RA: relative abundance. ${ }^{22-29}$ Organic compounds corresponding to peak numbers on the chromatogram referring to effluent $\mathrm{C}$ in Figure 4.

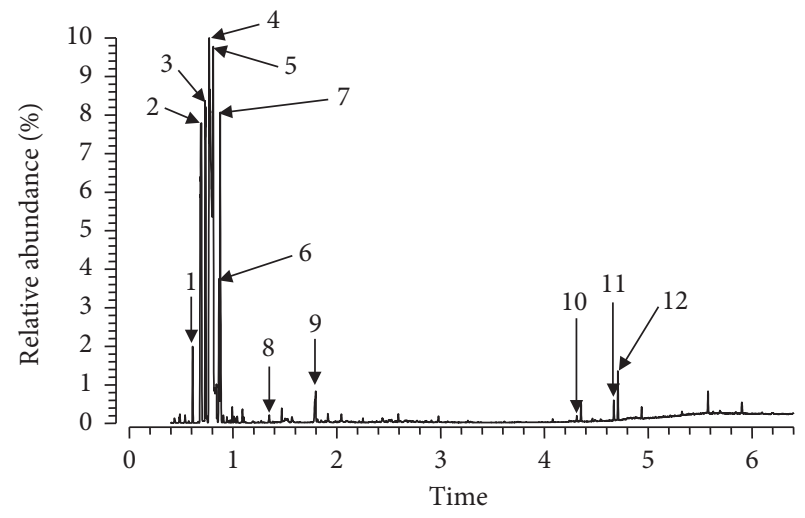

FIGURE 2: Total ion chromatograms of extracts of textile effluents A from the studied site. Peak numbers correspond to the chemical compounds indicated in Table 2.

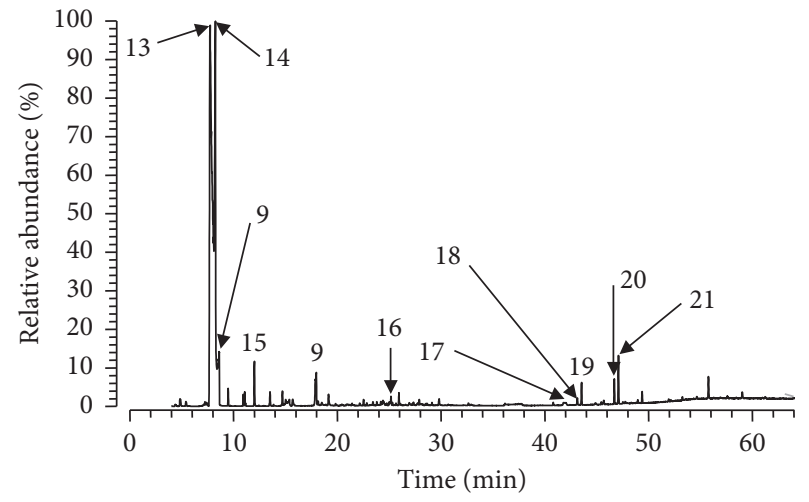

FIgURE 3: Total ion chromatograms of extracts of textile effluent B from the studied site. Peak numbers correspond to the chemical compounds indicated in Table 3. 




Figure 4: Total ion chromatograms of extracts of textile effluents C from the studied site. Peak numbers correspond to the chemical compounds indicated in Table 4.

Aromatic amines detected in the studied effluents are originating from dyes and pigments and are known to be potential hazards to human health and the environment $[32,70]$. Thus, untreated or incompletely treated textile effluent can be harmful to both aquatic and terrestrial life by adversely affecting the natural ecosystem and causing longterm health effects [71].

\section{Conclusion}

Different effluents from a textile industry of Fez city, Morocco, were collected and analyzed to determine the impact of textile industry on water pollution and human health. The water quality parameters like $\mathrm{BOD}_{5}, \mathrm{COD}$, TSS, and TDS of textile effluents were found to be significantly higher than the maximum permissible limit prescribed by M.D.Q.S and WHO. The results of this study clearly show that textile industry in Fez city, Morocco, is polluting the local aquatic environment. However, the numerous by-products of textile industry characterized in this study like benzoic acid, 2,3-dimethyl-6-(3-methyl-1-oxobutyl); 2-amino-4-hydroxy-6-p-cyanophenylpropylpteridine; phenol, 4-[2-[2-(chloromethyl)-1,3 dioxolan-2-yl]ethyl]; benzene, 1chloro-2-diethoxymethyl; and naphtho [2,3-d]-1,3-dioxol-5-ol, 3a,4,9,9a-tetrahydro-2,2-dimethyl-, cis, which are potentially toxic, can be used as typical indicators of textile contaminants in polluted aquatic systems. These compounds have a significant health hazard as it has been shown in a multitude of ecotoxicological studies on industrial effluents. The present research highlighted the diversity of organic compounds present in textile effluents. We discussed the toxicity of some organic compounds from the GC/MS analysis results (listed in Tables 2-4). Analysis of this type of effluents is very beneficial to the society and ecosystem. Therefore, there is a need to develop simple, costeffective and ecofriendly treatment systems for the remediation of textile effluents to minimize water pollution for sustainable environmental and economic development.

\section{Data Availability}

The data used to support the findings of this study are included within the article.

\section{Conflicts of Interest}

The authors declare that there are no conflicts of interest.

\section{Acknowledgments}

This study was supported by the Faculty of Sciences Dhar el Mahrez, Fez, Morocco.

\section{References}

[1] V. Lopez-Grimau, J. M. Guadayol, J. A. Griera, and M. C. Gutierrez, "Determination of non halogenated solvents in industrial wastewater using solid phase microextraction (SPME) and GC-MS," Latin American Applied Research, vol. 36, pp. 49-55, 2006.

[2] M. Castillo and D. Barcelo, "Characterization of organic pollutants in industrial effluents by high-temperature gas chromatography-mass spectrometry," Trends in Analytical Chemistry, vol. 18, no. 1, pp. 6-36, 1999.

[3] H. M. Pinheiro, E. Touraud, and O. Thomas, "Aromatic amines from azo dye reduction: status review with emphasis on direct UV spectrophotometric detection in textile industry wastewaters," Dyes and Pigments, vol. 61, no. 2, pp. 121-139, 2004.

[4] S. Bilgi and C. Demir, "Identification of photooxidation degradation products of C.I. Reactive Orange 16 dye by gas chromatography-mass spectrometry," Dyes and Pigments, vol. 66, no. 1, pp. 69-76, 2005.

[5] J. H. Weisburger, "A perspective on the history and significance of carcinogenic and mutagenic N-substituted aryl compounds in human health," Mutation Research/Fundamental and Molecular Mechanisms of Mutagenesis, vol. 376, no. 1-2, pp. 261-266, 1997.

[6] S. Monarca, A. Zanardini, D. Feretti et al., "Mutagenicity of extracts of lake drinking water treated with different disinfectants in bacterial and plant tests," Water Research, vol. 32, no. 9, pp. 2689-2695, 1998.

[7] N. Mathur, P. Bhatnagar, P. Nagar, and M. K. Bijarnia, "Mutagenicity assessment of effluents from textile/dye industries of Sanganer, Jaipur (India): a case study," Ecotoxicology and Environmental Safety, vol. 61, no. 1, pp. 105-113, 2005.

[8] N. Mathur and P. Bhatnagar, "Mutagenicity assessment of textile dyes from Sanganer (Rajasthan)," Journal of Environmental Biology, vol. 28, no. 1, pp. 123-126, 2007.

[9] L. Giorgetti, H. Talouizte, M. Merzouki, L. Caltavuturo, C. Geri, and S. Frassinetti, "Genotoxicity evaluation of effluents from textile industries of the region Fez-Boulmane, Morocco: a case study," Ecotoxicology and Environmental Safety, vol. 74, no. 8, pp. 2275-2283, 2011.

[10] L. Jieying, N. Xun-An, K. Minyi et al., "Elimination and ecotoxicity evaluation of phthalic acid esters from textiledyeing wastewater," Environmental Pollution, vol. 231, pp. 115-122, 2017.

[11] M. Castillo and D. Barceló, "Characterisation of organic pollutants in textile wastewaters and landfill leachate by using toxicity-based fractionation methods followed by liquid and gas chromatography coupled to mass spectrometric detection," Analytica Chimica Acta, vol. 426, no. 2, pp. 253-264, 2001.

[12] V. Prigione, V. Tigini, C. Pezzella, A. Anastasi, G. Sannia, and G. C. Varese, "Decolourisation and detoxification of textile 
effluents by fungal biosorption," Water Research, vol. 42, no. 12, pp. 2911-2920, 2008.

[13] V. Khandegar and A. K. Saroha, "Electrocoagulation for the treatment of textile industry effluent-a review," Journal of Environmental Management, vol. 128, pp. 949-963, 2013.

[14] L. Gebrati, M. El Achaby, H. Chatoui, M. Laqbaqbi, J. El Kharraz, and F. Aziz, "Inhibiting effect of textile wastewater on the activity of sludge from the biological treatment process of the activated sludge plant," Saudi Journal of Biological Sciences, vol. 26, no. 7, pp. 1753-1757, 2019.

[15] C. Allegre, M. Maisseu, F. Charbit, and P. Moulin, "Coagulation-flocculation-decantation of dye house effluents: concentrated effluents," Journal of Hazardous Materials, vol. 116, no. 1-2, pp. 57-64, 2004.

[16] K. Tak-Hyun, P. Chulhwan, Y. Jeongmok, and K. Sangyong, "Comparison of disperse and reactive dyes removals by chemical coagulation and Fenton oxidation," Journal of Hazardous Materials, vol. 112, pp. 95-103, 2004.

[17] V. Golob, A. Vinder, and M. Simonic, "Efficiency of the coagulation/flocculation method for the treatment of dyebath effluents," Dyes and Pigments, vol. 67, no. 2, pp. 93-97, 2005.

[18] A. Yurtsever, E. Sahinkaya, Ö. Aktaş, D. Uçar, Ö. Çınar, and Z. Wang, "Performances of anaerobic and aerobic membrane bioreactors for the treatment of synthetic textile wastewater," Bioresource Technology, vol. 192, pp. 564-573, 2015.

[19] S. H. Lin and C. F. Peng, "Continuous treatment of textile wastewater by combined coagulation, electrochemical oxidation and activated sludge," Water Research, vol. 30, no. 3, pp. 587-592, 1996.

[20] S. M. Ghoreishi and R. Haghighi, "Chemical catalytic reaction and biological oxidation for treatment of non-biodegradable textile effluent," Chemical Engineering Journal, vol. 95, no. 1-3, pp. 163-169, 2003.

[21] I. Kapdan and R. Oztekin, "The effect of hydraulic residence time and initial COD concentration on color and COD removal performance of the anaerobic-aerobic SBR system," Journal of Hazardous Materials, vol. 136, no. 3, pp. 896-901, 2006.

[22] N. Chahbane, S. Souabi, H. Almardhy et al., "Treatability assessment of textile wastewater in Morocco," Fresenius Environmental Bulletin, vol. 11, 2002.

[23] M. R. Islam and M. G. Mostafa, "Characterization of textile dyeing effluent and its treatment using polyaluminum chloride," Applied Water Science, vol. 10, no. 5, 2020.

[24] Moroccan Discharge Quality Standards in Surface Water or Groundwater, Joint Order of the Minister of the Interior, the Minister of Energy, Mines, Water and Environment, the Minister of Industry, Trade and New Technologies Minister and Crafts Minister, Moroccan Discharge Quality Standards in Surface Water or Groundwater, 2013.

[25] I. Kanbouchi, Contribution au traitement des eaux usées industrielles chargées en colorants et études de l'impact sur les réseaux d'assainissement, Ph.D. thesis, Faculty of Science Ben M'sik Casablanca, Hassan II University, Casablanca, Morocco, 2010.

[26] H. H. Rump, Laboratory Manual for the Examination of Water, Wastewater and Soil, VCH Publishers, Hoboken, NJ, USA, 2nd edition, 1992.

[27] N. Ali, A. Hameed, and S. Ahmed, "Physicochemical characterization and bioremediation perspective of textile effluent, dyes and metals by indigenous bacteria," Journal of Hazardous Materials, vol. 164, no. 1, pp. 322-328, 2009.

[28] P. B. Koli, K. H. Kapadnis, and U. G. Deshpande, "Study of physico-chemical properties, detection and toxicity study of organic compounds from effluent of MIDC Thane and GIDC Ankleshwar industrial zone," Applied Water Science, vol. 8, no. 7, 196 pages, 2018.

[29] M. Shammi, M. A. Kashem, M. M. Rahman, M. D. Hossain, R. Rahman, and M. K. Uddin, "Health risk assessment of textile effluent reuses as irrigation water in leafy vegetable Basella alba," International Journal of Recycling of Organic Waste in Agriculture, vol. 5, no. 2, pp. 113-123, 2016.

[30] C. A. Somensi, E. L. Simionatto, S. L. Bertoli, A. Wisniewski, and C. M. Radetski, "Use of ozone in a pilot-scale plant for textile wastewater pre-treatment: physico-chemical efficiency, degradation by-products identification and environmental toxicity of treated wastewater," Journal of Hazardous Materials, vol. 175, no. 1-3, pp. 235-240, 2010.

[31] Y.-X. Fang, G.-G. Ying, L.-J. Zhang et al., "Use of TIE techniques to characterize industrial effluents in the Pearl River Delta region," Ecotoxicology and Environmental Safety, vol. 76, pp. 143-152, 2012.

[32] S. Khan and A. Malik, "Environmental and health effects of textile industry wastewater," in Environmental Deterioration and Human Health, A. Malik, E. Grohmann, and R. Akhtar, Eds., Springer, Berlin, Germany, pp. 55-71, 2014.

[33] D.-H. Ahn, W.-S. Chang, and T.-I. Yoon, "Dyestuff wastewater treatment using chemical oxidation, physical adsorption and fixed bed biofilm process," Process Biochemistry, vol. 34, no. 5, pp. 429-439, 1999.

[34] R. O. Yusuff and J. A. Sonibare, "Characterization of textile industries effluents in Kaduna, Nigeria and pollution implications," Global NEST Journal, vol. 6, no. 3, pp. 212-221, 2004.

[35] E. I. Joseph, "Wastewater treatment in the textile industry," Pakistan Textile Journal, vol. 10, pp. 60-66, 2007.

[36] J. Paul, "Removal of COD and colour from textile wastewater using limestone and activated carbon," M.S. thesis, University Sains, George Town, Malaysia, 2008.

[37] K. Charoenlarp and W. Choyphan, "Reuse of dye wastewater through colour removal with electrocoagulation process," Asian Journal on Energy and Environment, vol. 10, no. 4, pp. 250-260, 2009.

[38] A. K. Verma, R. R. Dash, and P. Bhunia, "A review on chemical coagulation/flocculation technologies for removal of colour from textile wastewaters," Journal of Environmental Management, vol. 93, no. 1, pp. 154-168, 2012.

[39] J. Rodier, B. Leguebe, N. Merlet et al., L'analyse de l'eau, Dunod, Paris, France, 9th edition, 2009.

[40] G. Tamburlini, O. V. Ehrenstein, and R. Bertollini, "Children's health and environment: a review of evidence," Environmental Issue Report No. 129, WHO/European Environment Agency, Geneva, Switzerland, 2002.

[41] P. M. Chapman, G. P. Romberg, and G. A. Vigers, "Design of monitoring studies for priority pollutants," Journal of Water Pollution Control Federation, vol. 54, no. 3, pp. 292-297, 1982.

[42] C. M. A. Ademoroti, D. O. Ukponmwan, and A. A. Omode, "Studies of textile effluent discharges in Nigeria," International Journal of Environmental Studies, vol. 39, no. 4, pp. 291-296, 1992.

[43] L. E. Macaskie and A. C. R. Dean, "Cadmium accumulation by a Citrobacter sp," Microbiology, vol. 130, no. 1, pp. 53-62, 1984.

[44] H. Niu, X. S. Xu, J. H. Wang, and B. Volesky, "Removal of lead from aqueous solutions by Penicillium biomass," Biotechnology and Bioengineering, vol. 42, no. 6, pp. 785-787, 1993.

[45] P. Simmons, J. M. Tobin, and I. Singleton, "Considerations on the use of commercially available yeast biomass for the treatment of metal-containing effluents," Journal of Industrial Microbiology, vol. 14, no. 3-4, pp. 240-246, 1995. 
[46] D. Dadi, T. Stellmacher, F. Senbeta, S. Van Passel, and H. Azadi, "Environmental and health impacts of effluents from textile industries in Ethiopia: the case of Gelan and Dukem, Oromia Regional State," Environmental Monitoring and Assessment, vol. 189, no. 1, 2017.

[47] B. R. Babu, A. K. Parande, S. Raghu, and P. T. Kumar, "Textile processing and effluent treatment," Journal of Cotton Science, vol. 3, no. 3, pp. 143-153, 2007.

[48] P. K. Kumar and M. M. Pacha, "Assessment of phenolic compounds in the surface waters of Godavari Canal, Andhra Pradesh, India," Current World Environment, vol. 10, no. 1, pp. 338-342, 2015.

[49] A. B. dos Santos, F. J. Cervantes, and J. B. van Lier, "Review paper on current technologies for decolourisation of textile wastewaters: perspectives for anaerobic biotechnology," Bioresource Technology, vol. 98, no. 12, pp. 2369-2385, 2007.

[50] J. B. Klotz and L. A. Pyrch, "Neural tube defects and drinking water disinfection by-products," Epidemiology, vol. 10, no. 4, pp. 383-390, 1999.

[51] L. Dodds and W. D. King, "Relation between trihalomethane compounds and birth defects," Occupational and Environmental Medicine, vol. 58, no. 7, pp. 443-446, 2001.

[52] M. I. Cedergren, A. J. Selbing, O. Löfman, and B. A. J. Källen, "Chlorination byproducts and nitrate in drinking water and risk for congenital cardiac defects," Environmental Research, vol. 89, no. 2, pp. 124-130, 2002.

[53] D. A. Savitz, K. W. Andrews, and L. M. Pastore, "Drinking water and pregnancy outcome in central North Carolina: source, amount, and trihalomethane levels," Environmental Health Perspectives, vol. 103, no. 6, pp. 592-596, 1995.

[54] K. Waller, S. H. Swan, G. DeLorenze, and B. Hopkins, "Trihalomethanes in drinking water and spontaneous abortion," Epidemiology, vol. 9, pp. 134-140, 1998.

[55] D. A. Savitz, P. C. Singer, A. H. Herring et al., "Exposure to drinking water disinfection by-products and pregnancy loss," American Journal of Epidemiology, vol. 164, no. 11, pp. 1043-1051, 2006.

[56] L. Dodds, W. King, A. C. Allen, B. A. Armson, D. B. Fell, and C. Nimrod, "Trihalomethanes in public water supplies and risk of stillbirth," Epidemiology, vol. 15, no. 2, pp. 179-186, 2004.

[57] M. B. Toledano, M. J. Nieuwenhuijsen, N. Best et al., "Relation of trihalomethane concentrations in public water supplies to stillbirth and birth weight in three water regions in England," Environmental Health Perspectives, vol. 113, no. 2, pp. 225232, 2005.

[58] G. Bhaskar Raju, M. Thalamadai Karuppiah, S. S. Latha, D. Latha Priya, S. Parvathy, and S. Prabhakar, "Electrochemical pretreatment of textile effluents and effect of electrode materials on the removal of organics," Desalination, vol. 249, no. 1, pp. 167-174, 2009.

[59] A. Stolz, "Basic and applied aspects in the microbial degradation of azo dyes," Applied Microbiology and Biotechnology, vol. 56, no. 1-2, pp. 69-80, 2001.

[60] S. Venkata Mohan, N. C. Rao, and P. N. Sarma, "Simulated acid azo dye (Acid black 210) wastewater treatment by periodic discontinuous batch mode operation under anoxicaerobic-anoxic microenvironment conditions," Ecological Engineering, vol. 31, no. 4, pp. 242-250, 2007.

[61] D. Rawat, V. Mishra, and R. S. Sharma, "Detoxification of azo dyes in the context of environmental processes," Chemosphere, vol. 155, pp. 591-605, 2016.

[62] T. Platzek, C. Lang, G. Grohmann, U.-S. Gi, and W. Baltes, "Formation of a carcinogenic aromatic amine from an azo dye by human skin bacteria in vitro," Human \& Experimental Toxicology, vol. 18, no. 9, pp. 552-559, 1999.

[63] G. Oros, T. Cserhati, and E. Forgacs, "Strength and selectivity of the fungicidal effect of diazobenzene dyes," Fresenius Environmental Bulletin, vol. 10, pp. 319-322, 2001.

[64] E. Forgacs, T. Cserháti, and G. Oros, "Removal of synthetic dyes from wastewaters: a review," Environment International, vol. 30, no. 7, pp. 953-971, 2004.

[65] B.-Y. Chen, K.-W. Lin, Y.-M. Wang, and C.-Y. Yen, "Revealing interactive toxicity of aromatic amines to azo dye decolorizer Aeromonas hydrophila," Journal of Hazardous Materials, vol. 166, no. 1, pp. 187-194, 2009.

[66] B. Enric and C. Juan, "Aniline degradation by electro-Fenton ${ }^{\circledR}$ and peroxicoagulation processes using a flow reactor for wastewater treatment," Chemosphere, vol. 47, pp. 241-248, 2002.

[67] H. Takahashi and Y. Hashimoto, "Formaldehyde-mediated modification of natural deoxyguanosine with amines: one-pot cyclization as a molecular model for genotoxicity," Bioorganic \& Medicinal Chemistry Letters, vol. 11, no. 5, pp. 729-731, 2001.

[68] C. J. Smith, T. A. Perfetti, M. J. Morton et al., "The relative toxicity of substituted phenols reported in cigarette mainstream smoke," Toxicological Sciences, vol. 69, no. 1, pp. 265-278, 2002.

[69] V. Vallyathan, X. Shi, and V. Castranova, "Reactive oxygen species: their relation to pneumoconiosis and carcinogenesis," Environmental Health Perspectives, vol. 106, no. 5, p. 1151, 1998.

[70] N. Puvaneswari, J. Muthukrishnan, and P. Gunasekaran, "Toxicity assessment and microbial degradation of azo dyes," International Journal of Experimental Biology, vol. 44, pp. 618-626, 2006.

[71] K.-T. Chung, "Azo dyes and human health: a review," Journal of Environmental Science and Health, Part C, vol. 34, no. 4, pp. 233-261, 2016. 